\title{
Experimental Hydrogen Production in Hydrothermal and Fault Systems: Significance for Habitability of Subseafloor $\mathrm{H}_{2}$ Chemoautotroph Microbial Ecosystems
}

\author{
Katsuhiko Suzuki, Takazo Shibuya, Motoko Yoshizaki, and Takehiro Hirose
}

\begin{abstract}
Hydrogen generated in hydrothermal and fault systems has recently received considerable attention as a potential energy source for hydrogen-based microbial activity such as methanogenesis. Laboratory experiments that have reproduced conditions for the serpentinization of ultramafic rocks such as peridotite and komatiite have clarified the chemical and petrological processes of $\mathrm{H}_{2}$ production. In a frictional experimental study, we recently showed that abundant $\mathrm{H}_{2}$ can also be generated in a simulated fault system. This result suggests that microbial ecosystems might exist in subseafloor fault systems. Here we review the experimental constraints on hydrogen production in hydrothermal and fault systems.
\end{abstract}

\section{Keywords}

Friction experiment $\bullet$ Hydrogen generation $\cdot$ Hydrothermal experiment $\bullet$ Simulated fault system $•$ Ultramafic rocks

\subsection{Introduction}

The discovery of chemolithoautotrophic microbial ecosystems in the modern ocean has suggested that hydrothermal fluids enriched in $\mathrm{H}_{2}$ fuel $\mathrm{H}_{2}$-driven primary producers such as hyperthermophilic hydrogenotrophic

K. Suzuki (ه)

Institute for Research on Earth Evolution (IFREE), Japan Agency

for Marine-Earth Science and Technology (JAMSTEC),

2-15 Natsushima, Yokosuka 237-0061, Japan

Precambrian Ecosystem Laboratory, Japan Agency

for Marine-Earth Science and Technology (JAMSTEC),

2-15 Natsushima, Yokosuka 237-0061, Japan

Seafloor Resources Research Project (SRRP), Japan Agency

for Marine-Earth Science and Technology (JAMSTEC),

2-15 Natsushima, Yokosuka 237-0061, Japan

e-mail: katz@jamstec.go.jp

T. Shibuya

Precambrian Ecosystem Laboratory, Japan Agency

for Marine-Earth Science and Technology (JAMSTEC),

2-15 Natsushima, Yokosuka 237-0061, Japan methanogens (Cannat et al. 1997; Takai et al. 2004; Kelley et al. 2005) . Moreover, multidisciplinary studies have indicated that an $\mathrm{H}_{2}$-driven chemolithoautotrophic ecosystem may have supported the earliest life on Earth (Russell and Hall 1997; Sleep et al. 2004; Kelley et al. 2005; Canfield et al. 2006; Takai et al. 2006). $\mathrm{H}_{2}$-rich hydrothermal fluids are generated by the serpentinization of $\mathrm{Mg}$ - and Fe-rich ultramafic rocks, which are igneous and meta-igneous

Seafloor Resources Research Project (SRRP), Japan Agency for Marine-Earth Science and Technology (JAMSTEC), 2-15 Natsushima, Yokosuka 237-0061, Japan

M. Yoshizaki

Precambrian Ecosystem Laboratory, Japan Agency for Marine-Earth Science and Technology (JAMSTEC), 2-15 Natsushima, Yokosuka 237-0061, Japan

Department of Earth and Planetary Sciences, Tokyo Institute of Technology, 2-12-1 Ookayama, Meguro-ku, Tokyo 152-8551, Japan

T. Hirose

Kochi Institute for Core Sample Research, Japan Agency for Marine-Earth Science and Technology (JAMSTEC), 200 Monobe-otsu, Nankoku, Kochi 783-8502, Japan 
rocks consisting mainly ( $>90 \%$ ) of mafic minerals with high magnesium and iron contents. These rocks have a very low silica content $(<45 \%), \mathrm{MgO}$ generally more than $18 \%$, high $\mathrm{FeO}$, and low potassium. The Earth's mantle is composed of ultramafic rocks. The production of hydrogen by the serpentinization of ultramafic rocks is a central tenet of the hypothesis that life first emerged on Earth in an $\mathrm{H}_{2}$ rich hydrothermal environment (Russell et al. 2010).

In the modern ocean, the basement rocks of the oceanic crust are generally composed of mid-ocean ridge basalt (MORB). Along slow-spreading ridges such as the North Atlantic Ridge and the Southwest Indian Ridge, volcanic activity is low and severely serpentinized peridotites (peridotite: ultramafic rocks composed of olivine and pyroxene) are exposed along transform faults (e.g., Miyashiro et al. 1969; Aumento and Loubat 1971; Cannat 1993). Hydrogenenriched hydrothermal fluids are common in such peridotitedominated slow-spreading ridge settings (Kelley et al. 2001; Früh-Green et al. 2004). Since the first discovery of natural peridotite-hosted hydrothermal vents with abundant $\mathrm{H}_{2}$ at Logachev field on the Mid-Atlantic Ridge in 1995 (Krasnov et al. 1995), other peridotite-hosted and -associated hydrothermal vents have been found, namely, the Rainbow, Nibelungen, Lost City, and Achaze fields on the MidAtlantic Ridge (Charlou et al. 1998, 2002, 2008; Douville et al. 2002; Kelley et al. 2005; Melchert et al. 2008) and the Kairei field on the Central Indian Ridge (Van Dover et al. 2001). A pronounced feature of peridotite-hosted systems is the presence of hydrothermal solutions enriched not only in $\mathrm{H}_{2}$ but also in $\mathrm{CH}_{4}$ and other hydrocarbons (Charlou et al. 2002). Measured $\mathrm{H}_{2}$ concentrations in these fluids range from 2.5 to $16 \mathrm{mmol} / \mathrm{kg}$, with the highest concentrations reported at steady-state, unsedimented mid-ocean ridge hydrothermal vents. The generated $\mathrm{H}_{2}$ supports ecosystems, including hyperthermophilic subsurface lithoautotrophic ecosystems (HyperSLiME) (Takai et al. 2004; Nealson et al. 2005), in which methanogens utilize $\mathrm{H}_{2}$ and $\mathrm{CO}_{2}$ and produce methane as a metabolic product.

Several petrographical (Cressey 1979) and theoretical (Wetzel and Shock 2000; Sleep et al. 2004) studies have examined the $\mathrm{H}_{2}$-generating geochemical and mineralogical reactions associated with the serpentinization of ocean-floor ultramafic rocks, and experimental investigations (Berndt et al. 1996; Allen and Seyfried 2003; Seyfried et al. 2007) have significantly increased our understanding of the mechanisms of $\mathrm{H}_{2}$ production during serpentinization. In the present paper, we focus on these experimental results, because it is generally difficult to directly observe chemical processes in subseafloor environments. Thermodynamic modeling of seawater-peridotite reactions is also an important tool, both for understanding the experimental results and for inferring the natural serpentinization processes (Klein et al. 2009; McCollom and Bach 2009). McCollom and a

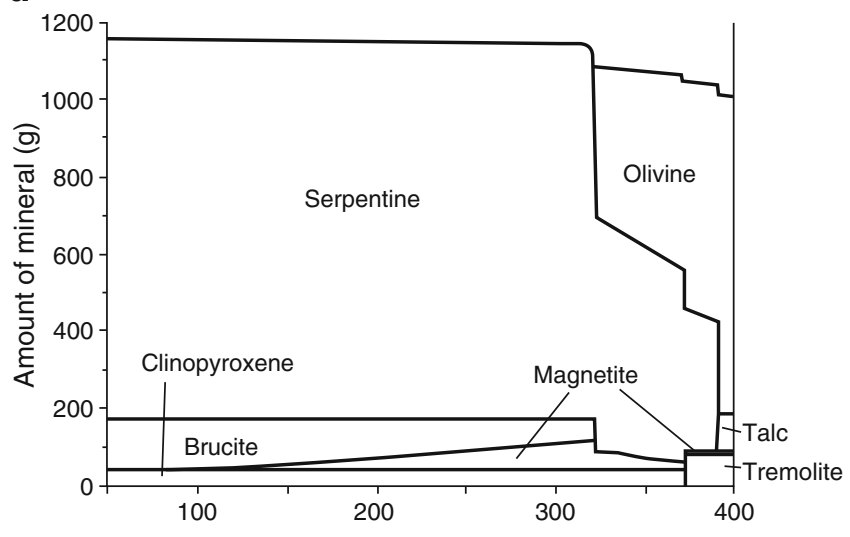

b

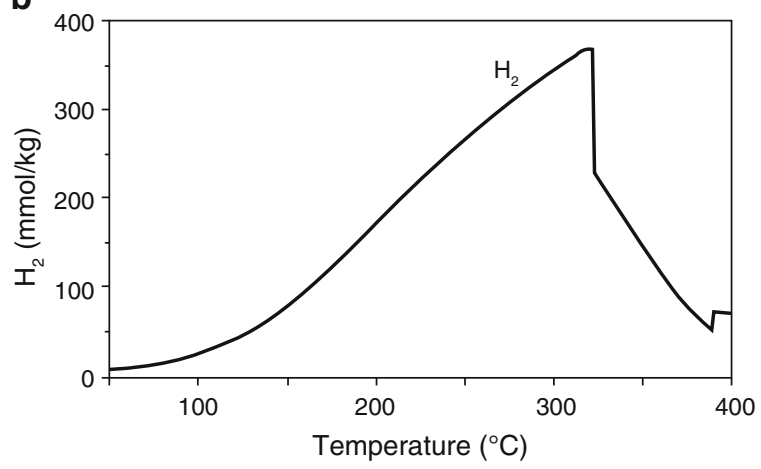

Fig. 8.1 Predicted alteration mineralogy and fluid composition during hydrothermal alteration of harzburgite over a range of temperatures at a 1:1 water:rock ratio, modified from McCollom and Bach (2009). (a) Equilibrium mineral composition: amount of each mineral per kilogram of harzburgite reacted. (b) $\mathrm{H}_{2}$ concentration in the fluid

Bach (2009) examined the effect of temperature on the mineral assemblage and fluid composition produced by serpentinization of harzburgite (a peridotite consisting mainly of olivine and orthopyroxene) (Fig. 8.1). They reported that at temperatures below $315{ }^{\circ} \mathrm{C}$, the serpentinized rock was composed of typical serpentinite minerals, such as serpentine, brucite, magnetite, and minor secondary clinopyroxene. With increasing temperature, the amount of magnetite increased, and consequently, the concentration of $\mathrm{H}_{2}$ generated by serpentinization also increased with temperature up to $\sim 360 \mathrm{mmol} / \mathrm{kg}$. Above $315^{\circ} \mathrm{C}$, however, olivine became stable and coexisted in equilibrium with other secondary minerals and fluid, and above $390{ }^{\circ} \mathrm{C}$ it remained almost completely unaltered. Therefore, the amount of $\mathrm{Fe}$ converted to magnetite decreased as the temperature increased above $315{ }^{\circ} \mathrm{C}$, with the result that the $\mathrm{H}_{2}$ concentration in the fluid was lower at these higher temperatures. Contrary to expectation, theoretical modeling of these water-rock interactions does not always produce results that are quantitatively consistent with the experimental results. Therefore, further investigation is needed to 
clarify the reasons for the discrepancy between theoretical and experimental results.

Another extreme environment where $\mathrm{H}_{2}$ may be abundant is found in natural fault systems. Wakita et al. (1980) first reported high concentrations of $\mathrm{H}_{2}$ (up to $3 \% \mathrm{v} / \mathrm{v}$ ) in soil gas from sites in the Yamasaki fault zone, southwestern Japan, and Wiersberg and Erzinger (2008) reported high concentrations of $\mathrm{H}_{2}$ in drilling cores obtained near microearthquake hypocenters along the San Andreas fault in California. These observations led to the hypothesis that methanogenic ecosystems might also be found in deep fault systems below the seafloor. To examine whether fault-driven $\mathrm{H}_{2}$ generation can produce enough $\mathrm{H}_{2}$ to maintain a chemolithoautotrophic microbial ecosystem, we conducted high-velocity sliding experiments using velocities and displacements typical of natural earthquakes (Hirose et al. 2011, 2012).

Thus, both hydrothermal and frictional experimental systems can be effectively used to elucidate physicochemical processes in natural systems. In this chapter, we review experiments, performed both as part of Project TAIGA (Trans-crustal Advection and In-situ bio-geochemical processes of Global sub-seafloor Aquifer) and by other groups, examining the generation of hydrogen by water/rock interactions at high temperature and pressure, including both reactions between water and komatiite, an Archean volcanic ultramafic rock, and those in frictional fault systems.

\subsection{Constraints on $\mathrm{H}_{2}$ Production During Experimental Hydrothermal Alteration of Ultramafic Rocks}

Peridotite exposed on slow-spreading ridge systems is often severely serpentinized as a result of hydration due to long-term reaction with seawater (Ildefonse et al. 2007; Morishita et al. 2009; Nakamura et al. 2009). Isotopic investigations have shown that such serpentinized peridotites, similar to altered MORB, are the products of high-temperature and -pressure reactions between peridotite and seawater (Wenner and Taylor 1971, 1973; Sakai and Tsutsumi 1978). Hydrothermal alteration of peridotite was studied experimentally (Seyfried and Dibble 1980; Hajash and Chandler 1981; Janecky and Seyfried 1986) even before the discovery of natural peridotite-hosted hydrothermal vents at Logachev field (Krasnov et al. 1995). Reactions between peridotite and seawater under high temperature and pressure have also been examined in batch-type experiments (see Chap. 7). Under high temperature and pressure, the oxidation of ferrous ion [Fe(II)] in primary minerals such as olivine and pyroxene to $\mathrm{Fe}$ (III) in secondary minerals such as magnetite reduces water and releases $\mathrm{H}_{2}$ gas:

$$
2(\mathrm{FeO})_{\text {mineral }}+\mathrm{H}_{2} \mathrm{O} \rightarrow\left(\mathrm{Fe}_{2} \mathrm{O}_{3}\right)_{\text {mineral }}+\mathrm{H}_{2}
$$

where $(\mathrm{FeO})_{\text {rock }}$ denotes the ferrous constituent of a primary silicate mineral such as olivine and $\left(\mathrm{Fe}_{2} \mathrm{O}_{3}\right)_{\text {rock }}$ denotes the ferric constituent of an secondary alteration mineral such as magnetite. The serpentinization of olivine $\left(\mathrm{Fo}_{90}\right)$ generates $\mathrm{H}_{2}$ as follows:

$$
\begin{gathered}
\underset{\text { Olivine }\left(\mathrm{Fo}_{90}\right)}{\mathrm{Mg}_{1.2} \mathrm{Fe}_{0.2} \mathrm{SiO}_{4}+1.37 \mathrm{H}_{2} \mathrm{O}} \rightarrow \underset{\text { Serpentine }}{0.5 \mathrm{Mg}_{3} \mathrm{Si}_{2} \mathrm{O}_{5}(\mathrm{OH})_{4}} \\
+\underset{\text { Brucite }}{0.3 \mathrm{Mg}(\mathrm{OH})_{2}}+\underset{\text { Magnetite }}{0.067 \mathrm{Fe}_{3} \mathrm{O}_{4}}+0.067 \mathrm{H}_{2}
\end{gathered}
$$

In this reaction, olivine supplies $\mathrm{Fe}(\mathrm{II})$, and hydrogen and magnetite, which contains $\mathrm{Fe}$ (II) and $\mathrm{Fe}(\mathrm{III})$ in equal amounts, are produced. Note that Eq. (8.2) is a simplified formula provided to illustrate the generation of $\mathrm{H}_{2}$ by serpentinization; in natural systems, the produced serpentine and brucite commonly contain Fe as well.

Janeckey and Seyfried (1986) experimentally investigated the serpentinization of harzburgite at $300{ }^{\circ} \mathrm{C}$ and $50 \mathrm{MPa}$, but they did not measure hydrogen continuously during their experiment. Instead, they collected samples for hydrogen measurement only twice, after 10 months and 2 years. In both samples, they found high concentrations of $\mathrm{H}_{2}(0.1$ and $0.33 \mathrm{mmol} / \mathrm{kg})$, but because they did not measure $\mathrm{H}_{2}$ in other fluid samples collected during the experiment, the $\mathrm{H}_{2}$ generation reaction cannot be unambiguously interpreted. Using a similar experimental apparatus, McCollom and Seewald (2001) assessed the potential of olivine serpentinization to reduce $\mathrm{CO}_{2}$ and produce hydrocarbons. In their experiments, they reacted powdered olivine with a $0.5 \mathrm{M} \mathrm{NaCl}$ solution at $300{ }^{\circ} \mathrm{C}$ and $35 \mathrm{MPa}$ and obtained abundant $\mathrm{H}_{2}$ (concentration $>70$ $\mathrm{mmol} / \mathrm{kg}$, Fig. 8.2) after $700 \mathrm{~h}$.

Allen and Seyfried (2003) reacted olivine, orthopyroxene, and clinopyroxene, the major constituent minerals in peridotite, with a $\mathrm{NaCl}-\mathrm{MgCl}_{2}$ solution at $400{ }^{\circ} \mathrm{C}$ and $50 \mathrm{MPa}$ to assess the potential of these minerals to produce $\mathrm{H}_{2}$. They used olivine $\left(\mathrm{Fo}_{89}\right)$, orthopyroxene $\left(\mathrm{En}_{85}\right)$, and clinopyroxene $\left(\mathrm{Di}_{89}\right)$ both individually and in combination to constrain the chemical processes of ultramafic-hosted hydrothermal systems in mid-ocean ridges. The olivine alteration rate was slow, as indicated by the absence of hydrous alteration products, whereas reactions including pyroxenes were rapid, resulting in significant increases in dissolved $\mathrm{H}_{2}$ as well as in $\mathrm{Ca}, \mathrm{SiO}_{2}$, and $\mathrm{Fe}$ (Fig. 8.3), and in the formation of $\mathrm{SiO}_{2}$-rich secondary minerals such as talc, tremolite, and magnetite (Fig. 8.3; McCollom and Bach 2009). High pH and low Fe 
concentrations are theoretically predicted under the assumption of full equilibrium at $400{ }^{\circ} \mathrm{C}$ and $50 \mathrm{MPa}$ in the $\mathrm{MgO}$ $\mathrm{CaO}-\mathrm{FeO}-\mathrm{Fe}_{2} \mathrm{O}_{3}-\mathrm{SiO}_{2}-\mathrm{Na}_{2} \mathrm{O}-\mathrm{H}_{2} \mathrm{O}-\mathrm{HCl}$ system (Allen and Seyfried 2003). In their laboratory experiments, however, Allen and Seyfried (2003) reported that when the initial olivine:pyroxene ratio was $3: 1$ (the typical mineral

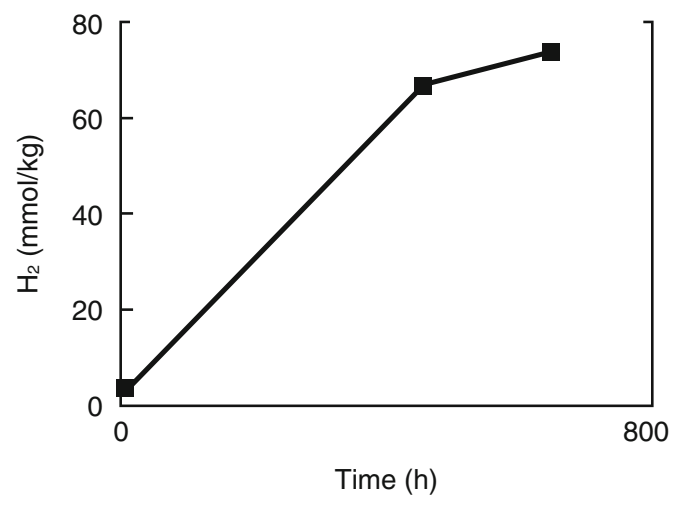

Fig. 8.2 Measured concentrations of dissolved $\mathrm{H}_{2}$ during a hydrothermal reaction in the presence of olivine at $300{ }^{\circ} \mathrm{C}$ and $35 \mathrm{MPa}$ as a function of reaction time. Modified from McCollom and Seewald (2001) composition of abyssal peridotite), $\mathrm{pH}$ remained low and $\mathrm{Fe}$ concentrations remained high. Moreover, the $\mathrm{pH}$ also remained relatively low in their experiments that included orthopyroxene and clinopyroxene, a result that may have been caused by talc-fluid and talc-tremolite-fluid equilibria, respectively.

Allen and Seyfried (2003) suggested that the reactions occurring in ultramafic rock-hosted hydrothermal systems such as the Rainbow system on the Mid-Atlantic Ridge may be very similar to those observed in these experiments, because of the similarity of the experimental conditions to the temperature and chemistry conditions of the vent fluid, in which concentrations of $\mathrm{SiO}_{2}, \mathrm{Ca}, \mathrm{H}_{2}$, and $\mathrm{Fe}$ are relatively high (Charlou et al. 1998, 2002). In fact, Fe concentrations in the Rainbow system, which are the highest of any vent system yet discovered, imply a relatively low $\mathrm{pH}$ in the subseafloor reaction zone. The findings of Allen and Seyfried (2003) are very important because the experimental results together with the observed Rainbow fluid chemistry suggest that pyroxene dissolution is the dominant reaction in the Rainbow hydrothermal system, even though abundant olivine is present in the reaction zone. To better constrain the temporal evolution of the hydrothermal alteration of ultramafic rocks in subseafloor reaction zones, experimental data

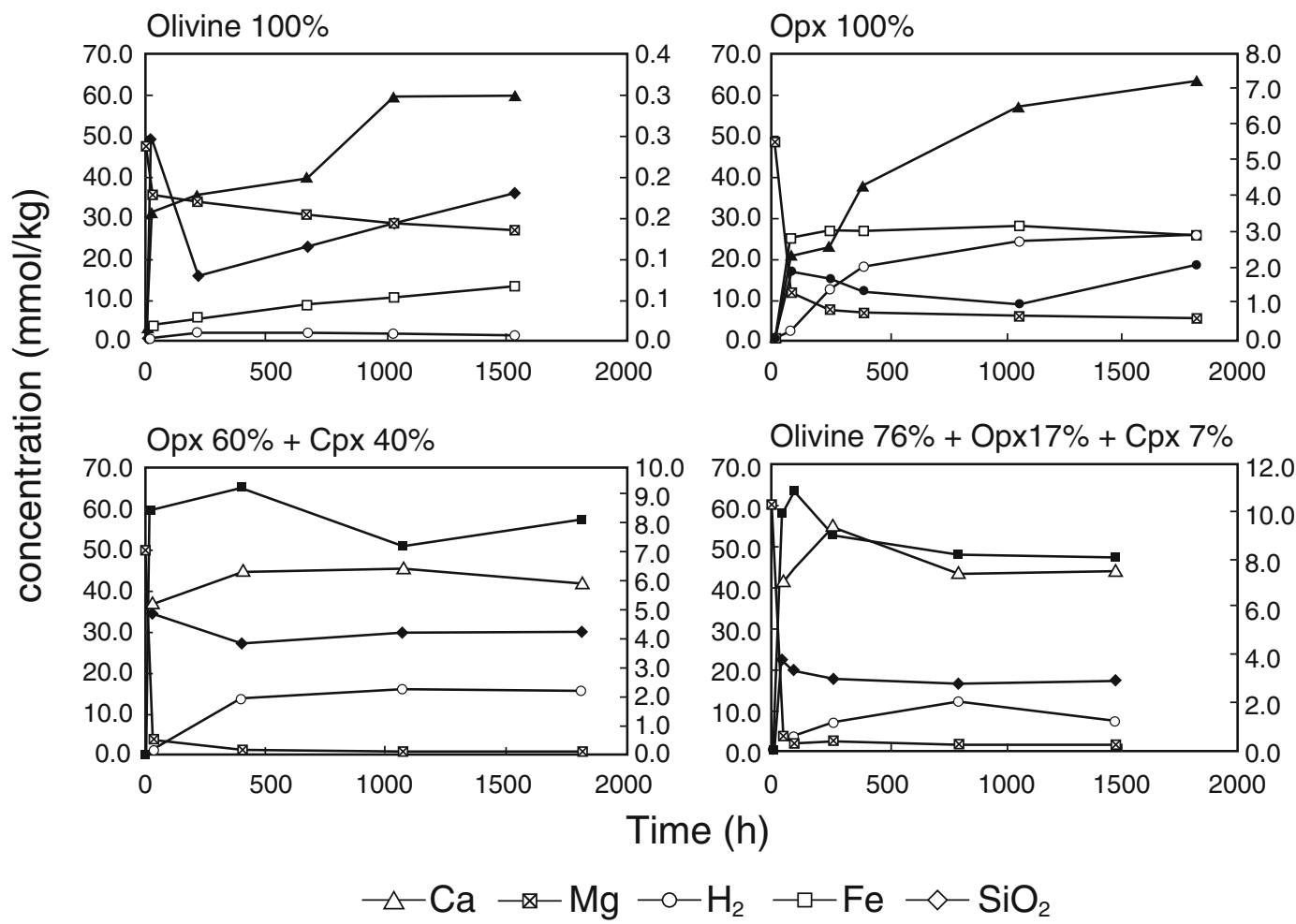

Fig. 8.3 Changes in the dissolved concentrations of selected species with time during four experiments, modified from Allen and Seyfried (2003). All experiments were performed at $400{ }^{\circ} \mathrm{C}, 50 \mathrm{MPa}$ and with mineral:fluid ratios from 2 to 4 . Values on the left vertical axis apply to

species represented by open symbols and to $\mathrm{Mg}$, and those on the right axis apply to species represented by closed symbols. Cpx clinopyroxene, $O p x$ orthopyroxene 


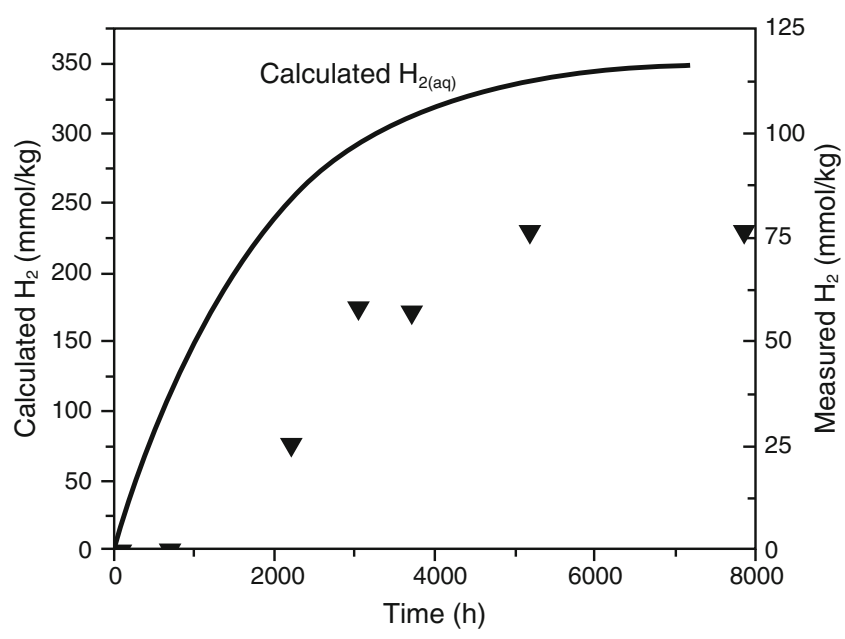

Fig. 8.4 Calculated (line) and measured (inverted triangles) timeseries changes in dissolved hydrogen in fluid coexisting with lherzolite and alteration products (Seyfried et al. 2007). The difference between measured and predicted dissolved $\mathrm{H}_{2}$ concentrations may reflect (in part) the lack of thermodynamic data for Fe-rich alteration minerals in the database used for the theoretical model

obtained under various conditions should be compared with thermodynamic simulation results.

The experiments just described were conducted at high temperatures $\left(300{ }^{\circ} \mathrm{C}\right.$ or higher), but actual reaction zone temperatures in ultramafic rocks are likely to be variable. For example, in the Lost City hydrothermal field on the MidAtlantic Ridge, $\mathrm{H}_{2}$ is abundant, the $\mathrm{pH}$ is high, and the reactions occur at moderately low temperature. When Seyfried et al. (2007) experimentally constrained hydrogen production at the low temperature of $200{ }^{\circ} \mathrm{C}$ and $50 \mathrm{MPa}$, they found that changes in the concentrations of $\mathrm{Ca}, \mathrm{Mg}$, and $\mathrm{Si}$ in the reacted fluid agreed quantitatively with those predicted theoretically by a reaction pathway model of seawater-lherzolite interaction (fluid:rock mass ratio, 1:1) at $200{ }^{\circ} \mathrm{C}$ and $50 \mathrm{MPa}$. However, the time variations of $\mathrm{pH}$, dissolved chloride, and $\mathrm{H}_{2}$ monitored during their experiment did not agree with the theoretically predicted results (Fig. 8.4). Dissolved $\mathrm{H}_{2}$ increased in a series of abrupt steps, and reached a maximum concentration that was only about $20 \%$ of the theoretically predicted concentration. Interestingly, serpentine, the most abundant alteration mineral, contained both ferric and ferrous iron, and magnetite was present only in trace amounts. They therefore inferred that the low rate of $\mathrm{H}_{2}$ generation, which was lower than that estimated on the basis of predicted serpentinization rates, was due to the production of diverse Fe-bearing alteration minerals.

In a recent experiment, Mayhew et al. (2013) reacted ultramafic and mafic rocks such as peridotite and minerals such as pyroxene, olivine, and magnetite with an anoxic fluid at $55^{\circ} \mathrm{C}$ and $100{ }^{\circ} \mathrm{C}$, temperatures that are habitable for (hyper)thermophilic microbes. Their synchrotron-based $\mathrm{X}$-ray analysis results showed that the amount of $\mathrm{H}_{2}$ produced was strongly dependent on whether spinel phases such as magnetite were present, and they observed $\mathrm{Fe}(\mathrm{III})$-oxide products on the surface of the spinels. They proposed, therefore, that $\mathrm{Fe}(\mathrm{II})$ and water adsorbed on the surface of spinels reacted together under kinetic control to produce $\mathrm{H}_{2}$ at low temperatures.

\subsection{Experimental $\mathrm{H}_{2}$ Generation During Komatiite Alteration: Simulation of an Archean Hydrothermal System}

The experiments described in Sect. 8.2 showed by simulating peridotite-seawater systems that abundant $\mathrm{H}_{2}$ is generated in a modern slow-spreading ridge by the serpentinization of peridotite. Sufficiently high concentrations of $\mathrm{H}_{2}$ occur in the vent fluids of these systems to sustain an ecosystem based on $\mathrm{H}_{2}$-driven chemolithoautotrophic primary producers such as methanogens. Moreover, an $\mathrm{H}_{2}$-driven ecosystem is the most probable candidate habitat for the earliest life on Earth (Russell and Hall 1997; Sleep et al. 2004; Kelley et al. 2005; Takai et al. 2006; Canfield et al. 2006). On this basis, it has been hypothesized that hydrothermal fluids with $\mathrm{H}_{2}$, sufficiently abundant to sustain methanogens, existed in the early Earth (Takai et al. 2006).

In contrast to the modern ocean, in the Hadean and early Archean ocean, peridotite was probably scarce beneath the crust of the ocean floor, because at that time the oceanic crust may have been two to three times the thickness of the modern oceanic crust (Ohta et al. 1996; Moores 2002; Takai et al. 2006). In this tectonic setting, komatiite, a distinctive ultramafic volcanic rock, was most likely the main component of ultramafic rocks on the floor of Hadean and Archean oceans. In fact, komatiite is common in Archean greenstone belts, whereas it is less common in Proterozoic successions and quite rare in Phanerozoic strata (Condie 2005). We therefore hypothesized that komatiite was the dominant ultramafic rock in the early history of the Earth (Yoshizaki et al. 2009) and that the interaction of komatiite with fluid at high temperature produced abundant $\mathrm{H}_{2}$. To test this hypothesis, we examined whether we could reproduce a hydrothermal environment habitable for early life by experimentally reacting komatiite with water.

Modern komatiite in exposed Archean rocks has already been severely altered, so komatiite in its present form could not be used for our experiments. Therefore, we synthesized komatiite glass by dehydrating and remelting serpentinized komatiite collected from the Komati Formation, Barberton Greenstone Belt, South Africa, and then reacted the synthesized komatiitic glass with an $\mathrm{NaCl}$ solution at $300{ }^{\circ} \mathrm{C}$ and $50 \mathrm{MPa}$ (Yoshizaki et al. 2009). 


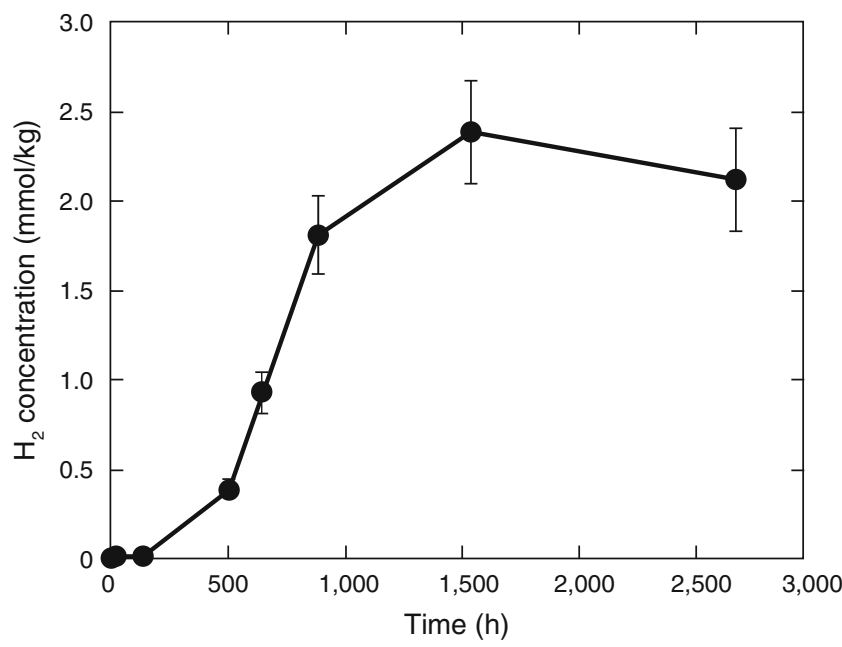

Fig. 8.5 Changes in the dissolved $\mathrm{H}_{2}$ concentration with time during a komatiitic glass-water reaction experiment (Yoshizaki et al. 2009). The experiment was performed at $300{ }^{\circ} \mathrm{C}$ and $50 \mathrm{MPa}$ with an initial water: rock ratio of $4: 1$

The concentration of produced $\mathrm{H}_{2}$ reached $2.4 \mathrm{mmol} / \mathrm{kg}$ after $1500 \mathrm{~h}$ (Fig. 8.5) (Yoshizaki et al. 2009). This concentration is comparable to concentrations obtained by hydration of peridotitic rocks (see Sect. 8.2). These results suggest that hydrothermal alteration of komatiite in the Hadean and early Archean may have provided sufficient $\mathrm{H}_{2}$ to fuel microbial ecosystems in the vicinity of hydrothermal vents.

\subsection{Mechanoradical $\mathrm{H}_{2}$ Generation During Simulated Faulting}

As we have described, hydrothermal alteration of peridotites and komatiites can produce abundant $\mathrm{H}_{2}$ in subseafloor settings. Other potential sites of $\mathrm{H}_{2}$ generation are active fault systems. Earthquake or fault-related $\mathrm{H}_{2}$ generation was first found by gas monitoring along the active Yamasaki fault, southwestern Japan (Wakita et al. 1980), and more recently $\mathrm{H}_{2}$ generation has been inferred from drill cores obtained near microearthquake hypocenters along the San Andreas fault in California (Wiersberg and Erzinger 2008). Kita et al. (1982) suggested that $\mathrm{H}_{2}$ may be generated in fault systems by the following reaction, expressed in terms of mechanoradicals on fresh surfaces of silicate minerals and water molecules:

$$
2(\equiv \mathrm{Si})^{\cdot}+2 \mathrm{H}_{2} \mathrm{O} \rightarrow 2(\equiv \mathrm{SiOH})+\mathrm{H}_{2}
$$

Experiments in which a ball mill was used to crush rocks had previously reproduced possible mechanoradical reactions during faulting (Kita et al. 1982; Kameda et al. 2004), but no quantitative investigations of the generation of $\mathrm{H}_{2}$ in an active fault system have been carried out. To

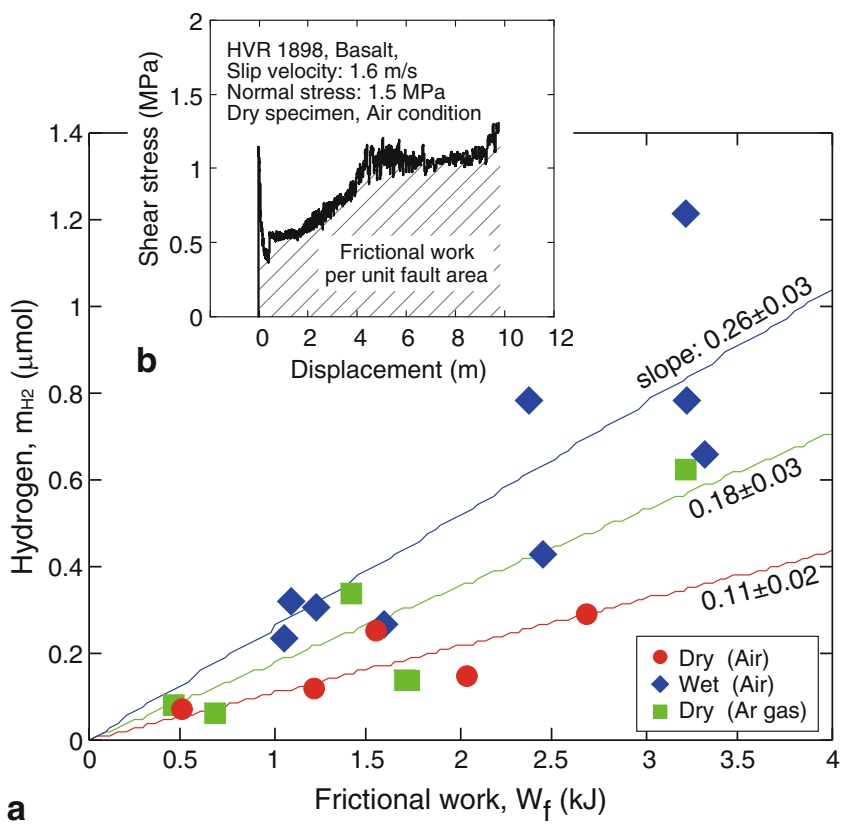

Fig. 8.6 (a) Hydrogen generation $(\mu \mathrm{mol})$ as a function of frictional work $(\mathrm{kJ})$ during high-velocity friction experiments with dry and wet basalt specimens at a slip velocity of $1.6 \mathrm{~m} / \mathrm{s}$ and a displacement of $10 \mathrm{~m}$ under an air or argon gas atmosphere (Hirose et al. 2011). The amount of hydrogen generated tended to increase linearly with frictional work (correlation coefficient of $0.814,0.899$, and 0.777 for wetair, dry-Ar gas, and dry-air conditions, respectively). (b) A typical shear stress versus displacement curve obtained during a friction experiment. Frictional work was calculated by integrating shear stress over the displacement (area under the shear stress versus displacement curve) and then multiplying the result by the fault surface area

examine whether a natural fault system can produce enough $\mathrm{H}_{2}$ to sustain a microbial methanogen-based ecosystem, we performed high-velocity sliding experiments that reproduced slip velocities and displacements typical of natural earthquakes and then quantitatively estimated the concentrations of $\mathrm{H}_{2}$ produced (Hirose et al. 2011). To collect the generated gas samples, we placed a reaction cell around the rock specimen in a high-velocity frictional experiment system (see Chap. 7 in this volume). The results showed that $\mathrm{H}_{2}$ generation increases with frictional work (i.e., earthquake magnitude) (Fig. 8.6). Therefore, the earthquake-derived $\mathrm{H}_{2}$ flux in nature can be estimated by establishing the correlation between $\mathrm{H}_{2}$ production and earthquake magnitude (Hirose et al. 2011, 2012). Moreover, an $\mathrm{H}_{2}$ fluid concentration higher than $1.1 \mathrm{mmol} / \mathrm{kg}$ can be achieved in a fault zone after even a smallmagnitude earthquake (Hirose et al. 2011, 2012). This concentration of $\mathrm{H}_{2}$ is potentially high enough to sustain a methanogen-based ecosystem, we can expect to find diverse microbial ecosystems in deep fault systems. Thus, such fault systems may also have provided habitable zones for early life on Earth. 


\subsection{Concluding Remarks and Future Perspectives}

In modern oceans, $\mathrm{H}_{2}$-rich hydrothermal fluids (i.e., $\mathrm{H}_{2}$ concentrations from a few to a few tens $\mathrm{mmol} / \mathrm{kg}$ ) have been observed in ultramafic rock-hosted systems. Such concentrations are sufficiently high to sustain $\mathrm{H}_{2}$-based lithoautotrophic microbial ecosystems, including phylogenetically ancient microbes (Takai et al. 2006). In this regard, the experiments simulating $\mathrm{H}_{2}$ generation described here have improved our understanding of not only geochemical and biological interactions driven by serpentinization in modern oceans but also the potential habitability of Hadean/Archean komatiite hydrothermal systems, in which life might have originated. Additionally, the results of friction experiments suggest the intriguing idea that $\mathrm{H}_{2}$ generated in a fault system might also sustain lithoautotrophic microbial ecosystems. Such fault system ecosystems may also have existed on the early Earth. To verify the fault zone model, we anticipate the results of microbial investigations of fault systems performed using fresh drill cores. It should be emphasized, however, that there are certain basic difficulties associated with the described hydrothermal experiments. For example, as described in Sect. 8.2, some results from experimental hydrothermal reactions conflict with both natural observations and theoretical calculations. The discrepancies may reflect mainly inappropriate initial experimental conditions or inaccurate thermodynamic data. Thus, future experiments must correct these problems.

Acknowledgments We thank Mamiko Umetsu for drawing some of the figures. Comments by Prof. Fumitaka Yanagisawa considerably improved our manuscript. This study was supported by a Grant-inAid for Scientific Research on Innovative Areas (no. 20109006) to "Project TAIGA: Trans-crustal Advection and In-situ bio-geochemical processes of Global sub-seafloor Aquifer" from the Ministry of Education, Culture, Sports, Science and Technology (MEXT) of Japan. We also thank Prof. Urabe and members of Project TAIGA for their collaboration and useful discussions.

Open Access This chapter is distributed under the terms of the Creative Commons Attribution Noncommercial License, which permits any noncommercial use, distribution, and reproduction in any medium, provided the original author(s) and source are credited.

\section{References}

Allen DE, Seyfried WE (2003) Compositional controls on vent fluids from ultramatic-hosted hydrothermal systems at mid-ocean ridges: an experimental study at $400{ }^{\circ} \mathrm{C}, 500$ bars. Geochim Cosmochim Acta 67:1531-1542. doi:10.1016/s0016-7037(02)01173-0

Aumento F, Loubat H (1971) The Mid-Atlantic Ridge near $45^{\circ} \mathrm{N}$, serpentinized ultramafic intrusions. Can J Earth Sci 8:631-663
Berndt ME, Allen DE, Seyfried WE (1996) Reduction of $\mathrm{CO}_{2}$ during serpentinization of olivine at $300^{\circ} \mathrm{C}$ and 500 bar. Geology 24:351-354

Canfield DE, Rosing MT, Bjerrum C (2006) Early anaerobic metabolisms. Philos Trans R Soc B Biol Sci 361:1819-1834

Cannat M (1993) Emplacement of mantle rocks in the seafloor at midocean ridges. J Geophys Res 98:4163-4172

Cannat M, Lagabrielle Y, Bougault H, Casey J, de Coutures N, Dmitriev L, Fouquet Y (1997) Ultramafic and gabbroic exposures at the Mid-Atlantic Ridge: geological mapping in the $15^{\circ} \mathrm{N}$ region. Tectonophysics 279:193-213

Charlou JL, Fouquet Y, Bougault H, Donval JP, Etoubleau J, JeanBaptiste P, Dapoigny A, Appriou P, Rona PA (1998) Intense $\mathrm{CH}_{4}$ plumes generated by serpentinization of ultramafic rocks at the intersection of the $15^{\circ} 20^{\prime} \mathrm{N}$ fracture zone and the Mid-Atlantic Ridge. Geochim Cosmochim Acta 62:2323-2333. doi:10.1016/ S0016-7037(98)00138-0

Charlou JL, Donval JP, Fouquet Y, Jean-Baptiste P, Holm N (2002) Geochemistry of high $\mathrm{H}_{2}$ and $\mathrm{CH}_{4}$ vent fluids issuing from ultramafic rocks at the Rainbow hydrothermal field $\left(36^{\circ} 14^{\prime} \mathrm{M}, \mathrm{MAR}\right)$. Chem Geol 191:345-359

Charlou JL, Donval JP, Konn C, Birot D, Sudarikov S, Jean-Baptiste P, Fouquet Y; Scientific Party of the Serpentine Cruise (2008) High hydrogen and abiotic hydrocarbons from new ultramafic hydrothermal sites between $12^{\circ} \mathrm{N}$ and $15^{\circ} \mathrm{N}$ on the Mid Atlantic RidgeResults of the SERPENTINE cruise, EOS Transactions, AGU, Fall Meeting Supplement, Abstract, 88, T51F-04

Condie KC (2005) Earth as an evolving planetary system. Elsevier, Burlington

Cressey BA (1979) Electron microscopy of serpentinite textures. Can Mineral 17:741-756

Douville E, Charlou JL, Oelkers EH, Bienvenu P, Jove Colon CF, Fouquet DJPY, Prieur D, Appriou P (2002) The rainbow vent fluids $\left(36^{\circ} 14^{\prime} \mathrm{M}, \mathrm{MAR}\right)$ : the influence of ultramafic rocks and phase separation on trace metal content in Mid-Atlantic Ridge hydrothermal fluids. Chem Geol 184:37-48

Früh-Green GL, James AD, Plas A, Kelley DS, Geobety B (2004) Serpentinization of oceanic peridotites: implications for geochemical cycles and biological activity. Subseafloor Biosphere Mid Ocean Ridges 144:119-136

Hajash A, Chandler GW (1981) An experimental investigation of hightemperature interactions between seawater and rhyolite, andesite, basalt and peridotite. Contrib Mineral Petrol 78:240-254

Hirose T, Kawagucci S, Suzuki K (2011) Mechanoradical $\mathrm{H}_{2}$ generation during simulated faulting: Implications for an earthquakedriven subsurface biosphere. Geophys Res Lett 38. doi:10.1029/ $2011 \mathrm{gl} 048850$

Hirose T, Kawagucci S, Suzuki K (2012) Correction to "Mechanoradical $\mathrm{H}_{2}$ generation during simulated faulting: implications for an earthquake-driven subsurface biosphere". Geophys Res Lett 39:L23304 doi:10.1029/2012GL054539

Ildefonse B, Blackman DK, John BE, Ohara Y, Miller DJ, MacLeod CJ (2007) Oceanic core complexes and crustal accretion at slowspreading ridges. Geology 35:623-626. doi:10.1130/G23531A.1

Janeckey DR, Seyfried WE Jr (1986) Hydrothermal serpentinization of peridotite within the oceanic crust: experimental investigations of mineralogy and major element chemistry. Geochim Cosmochim Acta 50:1357-1378

Janecky DR, Seyfried WE (1986) Hydrothermal serpentinization of peridotite within the oceanic-crust: experimental investigations of mireralogy and major element chemistry. Geochim Cosmochim Acta 50:1357-1378. doi:10.1016/0016-7037(86)90311-x

Kameda J, Saruwatari K, Tanaka H, Tsunomori F (2004) Mechanisms of hydrogen generation during the mechanochemical treatment of biotite within $\mathrm{D}_{2} \mathrm{O}$ media. Earth Planets Space 56:1241-1245

Kelley DS, Karson JA, Blackman DK, Fruh-Green GL, Butterfield DA, Lilley MD, Olson EJ, Schrenk MO, Roe KK, Lebon GT, Rivizzigno 
P, Party ATS (2001) An off-axis hydrothermal vent field near the Mid-Atlantic Ridge at 30 degrees N. Nature 412:145-149. doi:10. $1038 / 35084000$

Kelley DS, Karson JA, Fruh-Green GL, Yoerger DR, Shank TM, Butterfield DA, Hayes JM, Schrenk MO, Olson EJ, Proskurowski G, Jakuba M, Bradley A, Larson B, Ludwig K, Glickson D, Buckman K, Bradley AS, Brazelton WJ, Roe K, Elend MJ, Delacour A, Bernasconi SM, Lilley MD, Baross JA, Summons RT, Sylva SP (2005) A serpentinite-hosted ecosystem: the lost city hydrothermal field. Science 307:1428-1434. doi:10.1126/sci ence. 1102556

Kita I, Matsuo S, Wakita $\mathrm{H}$ (1982) $\mathrm{H}_{2}$ Generation by reaction between $\mathrm{H}_{2} \mathrm{O}$ and crushed rock: an experimental study on $\mathrm{H}_{2}$ degassing from the active fault zone. J Geophys Res 87:789-795. doi:10.1029/ JB087iB13p10789

Klein F, Bach W, Joens N, McCollom T, Moskowitz B, Berquo T (2009) Iron partitioning and hydrogen generation during serpentinization of abyssal peridotites from 15 degrees $\mathrm{N}$ on the MidAtlantic Ridge. Geochim Cosmochim Acta 73:6868-6893. doi:10. 1016/j.gca.2009.08.021

Krasnov SG, Cherkashev GA, Stepanova TV, Batuyev BN, Krotov AG, Malin BV, Maslob MN, Markov VF, Poroshina IM, Samovarov MS, Ashadze AM, Lazareva LI, Ermolayev IK (eds) (1995) Detailed geological studies of hydrothermal fields in the North Atlantic. Geological Society of London, Special Publication, pp 43-64

Mayhew LE, Ellison1 ET, McCollom TM, Trainor TP, Templeton AS (2013) Hydrogen generation from low-temperature water.rock reactions. Nat Geosci 6:478-484. doi:10.1038/NGEO1825.

McCollom TM, Bach W (2009) Thermodynamic constraints on hydrogen generation during serpentinization of ultramafic rocks. Geochim Cosmochim Acta 73:856-875. doi:10.1016/j.gca.2008. 10.032

McCollom TM, Seewald JS (2001) A reassessment of the potential for reduction of dissolved $\mathrm{CO}_{2}$ to hydrocarbons during serpentinization of olivine. Geochim Cosmochim Acta 65:3769-3778. doi:10.1016/ s0016-7037(01)00655-x

Melchert B, Devey CW, German CR, Lackschewitz KS, Seifert R, Walter M, Mertens C, Yoerger DR, Baker ET, Paulick H, Nakamura K (2008) First evidence for high-temperature offaxis venting of deep crustal/mantle heat: the Nibelungen hydrothermal field, southern Mid-Atlantic Ridge. Earth Planet Sci Lett 275:61-69

Miyashiro A, Shido F, Ewing M (1969) Composition and origin of serpentinites from the Mid-Atlantic Ridge near $24^{\circ}$ and $30^{\circ}$ North Latitude. Contrib Mineral Petrol 23:117-127

Moores EM (2002) Pre-1 Ga (pre-Rodinian) ophiolites: their tectonic and environmental implications. Geol Soc Am Bull 114:80-95. doi:10.1130/0016-7606(2002)114<0080:pgprot>2.0.co;2.

Morishita T, Hara K, Nakamura K, Sawaguchi T, Tamura A, Arai S, Okino K, Takai K, Kumagai H (2009) Igneous, alteration and exhumation processes recorded in abyssal peridotites and related fault rocks from an oceanic core complex along the Central Indian Ridge. J Petrol 50. doi:10.1093/petrology/egp025

Nakamura K, Morishita T, Bach W, Klein F, Hara K, Okino K, Takai K, Kumagai H (2009) Serpentinized troctolites exposed near the Kairei Hydrothermal Field, Central Indian Ridge: Insights into the origin of the Kairei hydrothermal fluid supporting a unique microbial ecosystem. Earth Planet Sci Lett 280:128-136. doi:10.1016/j.eps1. 2009.01.024

Nealson KH, Inagaki F, Takai K (2005) Hydrogen-driven subsurface lithoautotrophic microbial ecosystems (SLiMEs): do they exist and why should we care? Trends Microbiol 13:405-410. doi:10.1016/j. tim.2005.07.010

Ohta H, Maruyama S, Takahashi E, Watanabe Y, Kato Y (1996) Field occurrence, geochemistry and petrogenesis of the Archean mid- oceanic ridge basalts (AMORBs) of the Cleaverville area, Pilbara craton, western Australia. Lithos 37:199-221. doi:10.1016/00244937(95)00037-2

Russell MJ, Hall AJ (1997) The emergence of life from iron monosulphide bubbles at a submarine hydrothermal redox and $\mathrm{pH}$ front. J Geol Soc 154:377-402. doi:10.1144/gsjgs.154.3.0377

Russell MJ, Hall AJ, Martin W (2010) Serpentinization as a source of energy at the origin of life. Geobiology 8:355-371. doi:10.1111/j. 1472-4669.2010.00249.x

Sakai H, Tsutsumi M (1978) D/H fractionation factors between serpentine and water at $100{ }^{\circ} \mathrm{C}$ to $500{ }^{\circ} \mathrm{C}$ and 2000 bars water pressure, and the $\mathrm{D} / \mathrm{H}$ ratios of natural serpentines. Econ Geol 40:231-242

Seyfried WE Jr, Dibble WE Jr (1980) Seawater-peridotite interaction at $300{ }^{\circ} \mathrm{C}$ and 500 bars: implications for the origin of oceanic serpentinites. Geochim Cosmochim Acta 44:309-321

Seyfried WE Jr, Foustoukos DI, Fu Q (2007) Redox evolution and mass transfer during serpentinization: an experimental and theoretical study at $200{ }^{\circ} \mathrm{C}, 500$ bar with implications for ultramafic-hosted hydrothermal systems at Mid-Ocean Ridges. Geochim Cosmochim Acta 71:3872-3886. doi:10.1016/j.gca. 2007.05.015

Sleep NH, Meibom A, Fridriksson T, Coleman RG, Bird DK (2004), $\mathrm{H}_{2}$-rich fluids from serpentinization: geochemical and biotic implications. Proc Natl Acad Sci U S A 101:12818-12823

Takai K, Gamo T, Tsunogai U, Nakayama N, Hirayama H, Nealson KH, Horikoshi K (2004) Geochemical and microbiological evidence for a hydrogen-based, hyperthermophilic subsurface lithoautotrophic microbial ecosystem (HyperSLiME) beneath an active deep-sea hydrothermal field. Extremophiles 8:269-282. doi:10.1007/s00792-004-0386-3

Takai K, Nakamura K, Suzuki K, Inagaki F, Nealson KH, Kumagai H (2006) Ultramafics-Hydrothermalism-Hydrogenesis-HyperSLiME $\left(\mathrm{UltraH}^{3}\right)$ linkage: a key insight into early microbial ecosystem in the Archean deep-sea hydrothermal systems. Paleontologic Res 10:269-282

Van Dover CL, Humphris SE, Fornari D, Cavanaugh CM, Collier R, Goffredi SK, Hashimoto J, Lilley MD, Reysenbach AL, Shank TM, Von Damm KL, Banta A, Gallant RM, Gotz D, Green D, Hall J, Harmer TL, Hurtado LA, Johnson P, McKiness ZP, Meredith C, Olson E, Pan IL, Turnipseed M, Won Y, Young CR, Vrijenhoek RC (2001) Biogeography and ecological setting of Indian Ocean hydrothermal vents. Science 294:818-823. doi:10.1126/science.1064574

Wakita H, Nakamura Y, Kita I, Fujii N, Notsu K (1980) Hydrogen release: new indicator of fault activity. Science 210:188-190. doi:10.1126/science.210.4466.188

Wenner DB, Taylor HP (1971) Temperatures of serpentinization of ultramafic rocks, based on ${ }^{16} \mathrm{O} /{ }^{18} \mathrm{O}$ fractionation between coexisting serpentine and magnetite. Contrib Mineral Petrol 32:165-185

Wenner DB, Taylor HP (1973) Oxygen and hydrogen isotope studies of the serpentinization of ultramafic rocks in oceanic environments and continental ophiolite complexes. Am J Sci 273:207-239

Wetzel LR, Shock EL (2000) Distinguishing ultramafic- from basalthosted submarine hydrothermal systems by comparing calculated vent fluid compositions. J Geophys Res Solid Earth 105:8319-8340. doi:10.1029/1999JB900382

Wiersberg T, Erzinger J (2008) On the origin and spatial distribution of gas at seismogenic depths of the San Andreas Fault from drill mud gas analysis. Appl Geochem 23:1675-1690. doi:10.1016/j. apgeochem.2008.01.012

Yoshizaki M, Shibuya T, Suzuki K, Shimizu K, Nakamura K, Takai K, Omori S, Maruyama S (2009) $\mathrm{H}_{2}$ generation by experimental hydrothermal alteration of komatiitic glass at $300{ }^{\circ} \mathrm{C}$ and 500 bars: a preliminary result from on-going experiment. Geochem $\mathrm{J}$ 43: E17-E22 